\title{
糖尿病透析患者における胃運動障害と栄養状態に与える影響
}

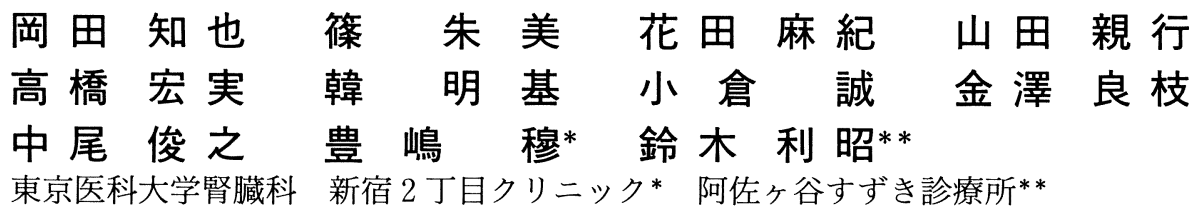

key words：血液透析，腹膜透析，胃排出能，栄養障害，糖尿病

〈要旨〉

糖尿病 (DM) 透析患者における胃運動機能を評価し, 胃運動障害が消化器症状の発現, 栄養状態に及ぼす影響に ついて, 非 DM 透析患者と比較検討した。 DM 血液透析 (HD) 患者 19 名, 非 DM-HD 患者 23 名, DM 腹膜透析 (CAPD) 患者 15 名, 非 DM-CAPD 患者 22 名の 4 群を対象に，アセトアミノフェン法により胃運動低下例(D例), 正常例（N例）に分類し，消化器症状，各種栄養指標に関する評価を行った。 HD, CAPD を合わせた DM 透析患 者は，非 DM 透析患者に比し有意にD例を多く認めた (65\% vs. 36\%, p=0.019). 各群別にみると，DM-HD 患 者の 58\%，非 DM-HD 患者の 39\%，DM-CAPD 患者の 73\%，非 DM-CAPD 患者の 32\%がD例に該当した。消化 器症状の有無を各群で検討したところ, 非 DM 透析患者では HD, CAPD とも D, N 例にかかわらず症状を認めな かったのに対し, DM 透析患者では HD のD例で 18\%, CAPD のD例で 73\%に消化器症状を認め, HD に比し CAPD に症状の出現頻度が高かった $(p=0.019)$. HD 患者では DM の罹患によらず $D, N$ 例間で BMI, 血清アルブミン, 筋肉量, PCR に差を認めなかった。一方 CAPD 患者において, DM 患者のD例は非 DM 患者の D, N 例や DM 患 者のN例との比較において筋肉量が最も低值であった。 以上より，DM 透析患者のうち CAPD 患者において，胃 運動障害を伴う場合には, 消化器症状を発現し易く, 食事摂取不足から生ずる栄養障害の一因となり得る可能性が 示唆された。

\section{Delayed gastric emptying in diabetic dialysis patients : its associations with gastrointestinal symptoms and nutritional status}

Tomonari Okada, Tamami Shino, Maki Hanada, Chikayuki Yamada, Hiromi Takahashi, MyeongGi Han, Makoto Ogura, Yoshie Kanazawa, Toshiyuki Nakao, Atsushi Toyoshima*, Toshiaki Suzuki** Division of Nephrology, Tokyo Medical College ; Shinjuku 2 chome Clinic*; Asagaya Suzuki Clinic**

Gastric motility was evaluated in chronic dialysis patients, and the role of delayed gastric emptying in the occurrence of gastrointestinal symptoms and nutritional status was compared in diabetics and non-diabetics. We classified 34 diabetics ( 19 hemodialysis (HD) patients and 15 continuous ambulatory peritoneal dialysis (CAPD) patients) and 45 non-diabetics (23 HD patients and 22 CAPD patients) as either having delayed gastric emptying ( $\mathrm{D}$ group) or normal gastric emptying ( $\mathrm{N}$ group) according to the serum levels of acetoaminophen following oral administration. Diabetics included more D group patients than non-diabetics (65\% vs. $36 \%$ ). D group included 39\% of non-diabetic (nonDM) HD patients, 58\% of diadetic (DM) HD patients, 32\% of nonDM-CAPD patients and $73 \%$ of DM-CAPD patients. D group non-diabetics did not complain of gastrointestinal symptoms irrespective of HD or CAPD. However, the number of patients who had symptoms was significantly greater in D group DM-CAPD patients than in DM-HD patients. There were no significant differences in nutritional variables between $\mathrm{D}$ group and $\mathrm{N}$ group among HD patients, irrespective of diabetes. In contrast, D group DM-CAPD patients showed the lowest muscle volume of all CAPD patients. It is concluded that delayed gastric emptying might be associated with the occurrence of gastrointestinal symptoms or poor nutritional status in DM-CAPD patients.

岡田 知也 東京医科大学腎臓科 $\bar{\top} 160$ 新宿区西新宿 6-7-1 (03-3342-6111)

〔受付: 平成 8 年 7 月 17 日, 受理：平成 8 年 12 月 2 日〕 
表 1 対象症例の群分け

\begin{tabular}{ccclllc}
\hline & $\mathrm{n}$ & 男/女 & \multicolumn{2}{c}{ 年齢 } & (歳) & \multicolumn{2}{c}{ 透析期間 $($ 月) } \\
\hline DM-HD & 19 & $13 / 6$ & $60 \pm 11$ & $(41 \sim 80)$ & $31 \pm 32$ & $(6 \sim 117)$ \\
DM-CAPD & 15 & $11 / 4$ & $57 \pm 8$ & $(47 \sim 70)$ & $23 \pm 25$ & $(1 \sim 93)$ \\
非 DM-HD & 23 & $13 / 10$ & $58 \pm 16$ & $(27 \sim 81)$ & $65 \pm 85$ & $(6 \sim 228)$ \\
非 DM-CAPD & 22 & $14 / 8$ & $53 \pm 10$ & $(36 \sim 74)$ & $26 \pm 22$ & $(5 \sim 107)$ \\
\hline
\end{tabular}

\section{緒 言}

維持透析患者において, 栄養障害は生命予後に関与 しており, 長期的な栄養管理は臨床上必須である ${ }^{1)}$. 特 に DM 透析患者では, 近年患者数が増加しているにも かかわらず2)，非 DM 透析患者との比較においても生 命予後は短いため ${ }^{3)}$ ，栄養状態を良好に維持すること は予後を改善させるための重要な要素であると考えら れる。透析患者に認められる栄養障害の最大の要因は 不十分なエネルギー，蛋白摂取であるが，これをもた らす因子の一つとして，胃運動障害による消化器症状 の影響が考えられている ${ }^{4,5)}$. 透析患者の胃運動機能に 関して，その成因に関する検討は若干なされている が6,7), 臨床面, 特に栄養状態に及ぼす影響については ほとんど検討されていない，本研究では，DM 透析患 者における胃運動機能を評価し, 胃運動障害が消化器 症状の発現, 栄養状態に及ぼす影響について非 DM 透 析患者と比較検討した。

\section{I. 対象と方法}

\section{1. 対 象}

外来透析患者 79 名を DM-HD 患者, DM-CAPD 患 者, 非 DM-HD 患者, 非 DM-CAPD 患者の 4 群に 分けて検討した。 各群の平均年噛, 透析期間, 性別は 表 1 に示した。対象患者は全て, 検討時において胃, 十二指腸の器質的疾患を持たず，胃運動能に直接影響 する薬剤を服用していない.また肝疾患患者は除外し， CAPD 患者では 1 か月以内に腹膜炎に罹患していな い.

\section{2. 方 法}

\section{1）胃運動機能の評価}

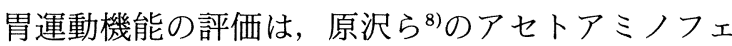
ン法を改変して行った。検査当日は通常どおり朝食お よび内服を行い, HD 患者は午前 8〜 9 時, CAPD 患 者は午前 9 時〜午後 1 時の間に透析液を腹腔に貯留し た状態で検査を施行した。アセトアミノフェン $1.5 \mathrm{~g}$
を水 $150 \mathrm{~m} l$ で服用し，15，45，60 分後に採血し，血 中濃度を測定した．各症例において血中濃度 $15 ， 45$, 60 分值が $10,10,12 \mu \mathrm{g} / \mathrm{m} l$ 末満を全て満たす場合を 胃運動低下例（D例），それ以外を正常例（N例）に分 類した. なおコントロールとして健常人 11 名(平均年 歯 $30 \pm 5$ 歳）に同様に検査を行った。

2 ) 消化器症状の評価

問診により，悪心，嘔吐，食欲の 3 項目について症 状のスコア化を行った。

[悪心] 0 ；全くない，1；ほとんどない，2：時々 ある， 3 ；常にある

[嘔吐］ 0 ；全くない，1；ほとんどない，2：たま にある， 3 ；時々ある

[食欲] 0 ；常に良好，1；たまにない，2：時々な い, 3 ; 常に全くない

以上の総点が 3 点以上の症例を症状 $(+)$ 例とした.

3 ）栄養状態の評価

対象患者に以下の項目を測定，算出した。

1. 血清尿素窒素 (BUN)，クレアチニン $(\mathrm{Cr})$ ，ア ルブミン (Alb), トランスフェリン

2. Body mass index (BMI), \% ideal body weight (\% IBW)

体重は検査時の dry weight とした。 \% IBW は標 準体重（BMI22 となる体重）に対する dry weight の 比とした。

3. \% Muscle volume (\% MV)

上腕周囲径と皮下脂肪厚を測定し，既報の方法に基 づき上腕部幅 $1 \mathrm{~cm}$ 当たりの骨格筋容量を算出し $た^{9)}$. 次に，同報告の男女別健常人の骨格筋容量の平均 值に対する比を \% MV として算出した

4. Normalized protein catabolic rate (nPCR)

$\mathrm{HD}$ 患者は PCR $(\mathrm{g} /$ day $)=6.25(\mathrm{Gu}+\mathrm{UUN} \times \mathrm{UV} /$ $1000+0.031 \mathrm{DW})$ により算出した.

$\mathrm{Gu}$ : 尿素窒素産生量 $(\mathrm{g} / \mathrm{day}), \mathrm{UUN}$ ：尿中尿素窒 素 $(\mathrm{mg} / \mathrm{d} l) ， \mathrm{UV}: 24$ 時間尿量 $(\mathrm{d} l), \quad \mathrm{DW}$ ：dry weight $(\mathrm{kg})$.

$\mathrm{Gu}=24(\mathrm{~V} 2 \mathrm{C} 2-\mathrm{V} 1 \mathrm{C} 1) / \theta / 1000$

$\mathrm{V} 2, \mathrm{C} 2$ : 透析前体液量 $(\mathrm{d} l), \mathrm{BUN}(\mathrm{mg} / \mathrm{d} l), \mathrm{V} 1$, 
(\%)

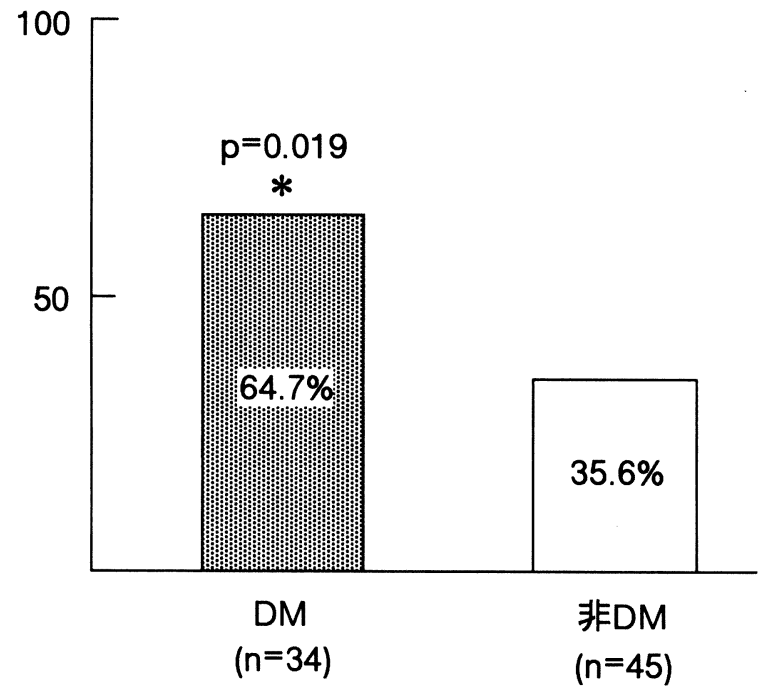

図胃運動低下例（D例）の割合（HD+CAPD）

$\mathrm{C} 1$ : 前回透析後体液量, BUN, $\theta$ : 透析間時間 (hr). 体液量は体重の $60 \%$ と仮定した。 また一日非尿素窒素 産生量を $31 \mathrm{mg} / \mathrm{kg} /$ day と仮定した ${ }^{10}$.

$\mathrm{CAPD}$ 患者は $\mathrm{PCR}=7.31(\mathrm{UN} \times \mathrm{V}+\mathrm{UUN} \times \mathrm{UV}) /$ $1000+13$ により算出した ${ }^{111}$. UN : PD 排液尿素窒素 $(\mathrm{mg} / \mathrm{d} l), \mathrm{V}$ : 一日総排液量 $(\mathrm{d} l)$.

$\mathrm{HD}$ 患者は非透析日に 24 時間蓄尿を行い, CAPD 患者は一日の PD 排液の採取時に蓄尿を行った。各患 者の PCR を標準体重で除して $\mathrm{nPCR}(\mathrm{g} / \mathrm{kg} /$ day) と した.

以上の項目について, DM, 非 DM 透析患者間で, $\mathrm{D}$ 例， N例に分けて比較検討した。

4 ) 統計処理

各々の值は平均土標準偏差で表した。多群間の検定 は一元配置分散分析法 (one-way ANOVA) を用い, Fisher's PLSD 法により群間比較を行った。 2 群間の 検定は unpaired $t$-test を，他に $\chi^{2}$ 検定を用いた。 危険率 (p) が 0.05 未満を有意差ありと判定した.

\section{II. 結 果}

\section{1. 胃運動機能}

HD, CAPD を合わせた DM 34 名, 非 DM 45 名の 間で比較すると, DM 22 名 (64.7\%), 非 DM 16 名 $(35.6 \%)$ が D例に該当し，DM 透析患者に有意に多く $\mathrm{D}$ 例を認めた $(\mathrm{p}=0.019)$ （図 1).

D例の割合を各群別にみると DM-CAPD 患者が $73 \%$ と最も多いが，統計学的に 4 群間で頻度の有意差 は認めなかった（表 2）。
表 2 胃運動低下例（D例）の割合

\begin{tabular}{lcc}
\hline \multirow{2}{*}{$\mathrm{NM}$} & $\mathrm{HD}$ & $11 / 19(58 \%)$ \\
\cline { 2 - 3 } & $\mathrm{CAPD}$ & $11 / 15(73 \%)$ \\
\hline \multirow{2}{*}{ 非 DM } & $\mathrm{HD}$ & $9 / 23(39 \%)$ \\
\cline { 2 - 3 } & $\mathrm{CAPD}$ & $7 / 22(32 \%)$ \\
\hline control & & $0 / 11$ \\
\hline
\end{tabular}

表 3 消化器症状を有する症例の割合

\begin{tabular}{lccc}
\hline & & $\mathrm{D}$ 例 & $\mathrm{N}$ 例 \\
\hline \multirow{2}{*}{ DM } & $\mathrm{HD}(\mathrm{n}=19)$ & $2 / 11(18 \%)$ & $2 / 8(25 \%)$ \\
\cline { 2 - 4 } & $\mathrm{CAPD}(\mathrm{n}=15)$ & $8 / 11(73 \%) * *$ & $0 / 4(0 \%)$ \\
\hline \multirow{2}{*}{ 非 DM } & $\mathrm{HD}(\mathrm{n}=23)$ & $0 / 9(0 \%)$ & $0 / 14(0 \%)$ \\
\cline { 2 - 4 } & $\mathrm{CAPD}(\mathrm{n}=22)$ & $0 / 7(0 \%)$ & $0 / 15(0 \%)$ \\
\hline & & & $* * \mathrm{p}=0.019$
\end{tabular}

\section{2. 胃運動機能と消化器症状}

$\mathrm{D}$ 例に該当する $\mathrm{DM}$ 透析患者では, DM-HD 患者 の $18 \%$ ( 2 名/11 名), DM-CAPD 患者の 73\%（8 名/ 11 名）が症状 $(+)$ 例であり, HD に比し CAPD に 有意に多く症状 $(+)$ 例を認めた $(\mathrm{p}=0.019)$ 。一方 D例に該当する非 DM 透析患者では HD, CAPD とも に症状（十）例を認めなかった（表 3 ）。

N例に該当する患者では, DM-HD 患者に 8 名中 2 名が症状 $(+)$ 例であったが, DM-CAPD 患者や非 DM 透析患者には症状 $(+)$ 例を認めなかった。

\section{3. 胃運動機能と栄養状態}

対象の 4 群を各々 $\mathrm{D}, \mathrm{N}$ 例に分け栄養指標を比較し た. DM-HD, 非 DM-HD 患者では D, N 例によらず 各項目に有意差を認めなかった（表 4 ）。一方 DMCAPD 患者の D 例は, 非 DM-CAPD 患者の D 例に比 し BMI, \% IBW, Cr, \% MV が，非 DM-CAPD 患者 のN例に比し BUN, Cr, Alb, nPCR, \% MV が有意に 低值であった(表 5 )。ささに DM-CAPD 患者のD例, $\mathrm{N}$ 例間の比較では, \% $\mathrm{MV}$ のみ $\mathrm{D}$ 例が $\mathrm{N}$ 例に比し有意 に低值であった。

\section{III. 考 察}

透析患者の胃運動機能に関して, 現在までにアセト アミノフェン法, アイソトープ法を用い検討がなされ

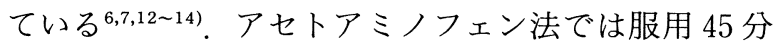
後の血中濃度に基づいて胃運動能の評価が行われる が，従来の報告でもみられるように血中濃度は幅広い 分布となり, 再現性はある程度認められるものの，そ の絶対值自体の評価は難しい ${ }^{12,15,16)}$ ，本検討では対象 を $\mathrm{D}, \mathrm{N}$ 例の 2 群に分けて評価した。その結果 DM 罹 
表 4 HD 患者のD例, N例間における各指標の比較

\begin{tabular}{cccccc}
\hline & \multicolumn{3}{c}{ 非 DM } & & \multicolumn{2}{c}{$\mathrm{DM}$} \\
\cline { 2 - 3 } \cline { 5 - 6 } & $\begin{array}{c}\mathrm{D} \text { 例 } \\
(\mathrm{n}=9)\end{array}$ & $\begin{array}{c}\mathrm{N} \text { 例 } \\
(\mathrm{n}=14)\end{array}$ & & $\begin{array}{c}\mathrm{D} \text { 例 } \\
(\mathrm{n}=11)\end{array}$ & $\begin{array}{c}\mathrm{N} \text { 例 } \\
(\mathrm{n}=8)\end{array}$ \\
\hline BMI & $21.7 \pm 2.3$ & $20.3 \pm 2.6$ & & $22.1 \pm 2.6$ & $20.1 \pm 1.5$ \\
\%IBW (\%) & $98.7 \pm 10.2$ & $92.2 \pm 11.9$ & & $100.3 \pm 11.8$ & $91.1 \pm 7.0$ \\
BUN (mg/d $l)$ & $79.8 \pm 14.8$ & $75.1 \pm 11.9$ & & $76.3 \pm 15.6$ & $74.6 \pm 16.7$ \\
Cr (mg/d $l)$ & $11.5 \pm 3.2$ & $9.4 \pm 3.1$ & & $10.1 \pm 3.0$ & $9.9 \pm 2.2$ \\
Albumin (g/d $l)$ & $3.9 \pm 0.3$ & $3.9 \pm 0.4$ & & $3.8 \pm 0.3$ & $4.0 \pm 0.3$ \\
Transferrin (mg/d $l)$ & $217 \pm 41$ & $228 \pm 50$ & & $244 \pm 43$ & $246 \pm 63$ \\
$\mathrm{nPCR}(\mathrm{g} / \mathrm{kg} / \mathrm{day})$ & $1.07 \pm 0.15$ & $1.05 \pm 0.19$ & & $1.11 \pm 0.25$ & $0.99 \pm 0.14$ \\
$\% \mathrm{MV}(\%)$ & $97.3 \pm 28.4$ & $87.9 \pm 31.2$ & & $83.9 \pm 23.7$ & $76.7 \pm 25.4$ \\
\hline
\end{tabular}

表 $5 \mathrm{CAPD}$ 患者のD例， N例間における各指標の比較

\begin{tabular}{|c|c|c|c|c|}
\hline & \multicolumn{2}{|c|}{ 非 DM } & \multicolumn{2}{|c|}{ DM } \\
\hline & $\begin{array}{c}\mathrm{D} \text { 例 } \\
(\mathrm{n}=7)\end{array}$ & $\begin{array}{c}\mathrm{N} \text { 例 } \\
(\mathrm{n}=15)\end{array}$ & $\begin{array}{c}\mathrm{D} \text { 例 } \\
(\mathrm{n}=11)\end{array}$ & $\begin{array}{c}\mathrm{N} \text { 例 } \\
(\mathrm{n}=4)\end{array}$ \\
\hline BMI & $22.6 \pm 3.1$ & $20.7 \pm 1.8$ & ${ }_{19.8 \pm 2.4}^{*}$ & $22.4 \pm 3.7$ \\
\hline \%IBW (\%) & $102.7 \pm 14.3$ & $94.2 \pm 8.1$ & $\begin{array}{c}8^{*} \\
88.9 \pm 11.1\end{array}$ & $101.6 \pm 17.0$ \\
\hline $\mathrm{BUN}(\mathrm{mg} / \mathrm{d} l)$ & $60.0 \pm 9.8$ & $62.4 \pm 14.6$ & $\begin{array}{c}{ }^{*} \\
49.4 \pm 14.0\end{array}$ & $57.1 \pm 20.1$ \\
\hline $\mathrm{Cr}(\mathrm{mg} / \mathrm{d} l)$ & $12.0 \pm 2.1$ & $\begin{array}{r}* \\
11.0 \pm 3.1\end{array}$ & $8.8 \pm 1.8$ & $9.8 \pm 3.2$ \\
\hline Albumin $(\mathrm{g} / \mathrm{d} l)$ & $3.7 \pm 0.5$ & $\begin{array}{c} \\
3.8 \pm 0.4\end{array}$ & $\begin{array}{r}{ }^{* *} \\
3.4 \pm 0.4\end{array}$ & ${ }_{3.3 \pm 0.2}^{*}$ \\
\hline Transferrin $(\mathrm{mg} / \mathrm{d} l)$ & $213 \pm 49$ & $228 \pm 50$ & $205 \pm 60$ & $214 \pm 19$ \\
\hline nPCR (g/kg/day) & $0.90 \pm 0.12$ & $1.00 \pm 0.35$ & $\bar{c}^{*}{ }^{*} 0.15$ & $0.86 \pm 0.21$ \\
\hline$\% \mathrm{MV}(\%)$ & $\begin{array}{c}* * * \\
73.6 \pm 13.1\end{array}$ & $\begin{array}{l}* * * \Gamma \\
83.8 \pm 17.8\end{array}$ & $49.5 \pm 13.1$ & ${ }_{75.2 \pm 17.5}^{*}$ \\
\hline
\end{tabular}

患の有無,さらに HD, CAPD によらずD例を認め, 透析患者には一定の割合で胃運動障害がみられると考 えられた。DM患者は従来糖尿病性胃麻痺（gastroparesis diabeticorum) といわれる特有の症候を呈し， 末期腎不全に至っていない患者においても約 50\%に 胃運動障害を認めることが知られており ${ }^{17,18)}$, 本検討 においても HD, CAPD 患者ともに $50 \%$ 以上の高い割 合でD例を認めた。一方非 DM 透析患者については, 健常人とほぼ同等の胃運動機能であるという報告もあ るが6,7)，本検討では HD, CAPD 患者ともに約 30\%が D例に該当した。 DM 透析患者が非 DM 透析患者に 比し高頻度に胃運動障害を認める原因として, 糖尿病 性自律神経障害の部分的なあらわれとしての迷走神経 障害の影響が第一に考えられる。またガストリン，モ チリン等の消化管ホルモンの作用異常, 高血糖等の複 数の要因によって起きやすくなると考えられる ${ }^{17,18)}$. 一方非 DM 透析患者においては, 自律神経障害は必ず
しも認められず胃運動障害との関連性は乏しいと考え られ6,7)，なぜ一部の患者にのみ胃運動障害を認めるの かは不明である。

CAPD 患者において透析液の貯留自体が胃運動低 下を起こし得るという報告があるが14)，本検討では全 員が貯留した状態で検査を行っており，HD患者と比 較してD例の割合, アセトアミノフェン血中濃度の推 移はほぼ同等であり，影響はないと思われる。

本検討では非 DM-HD, 非 DM-CAPD 患者におい て $\mathrm{D}, \mathrm{N}$ 例によらず消化器症状を認めなかった。一方 $\mathrm{DM}$ 透析患者においては, D例に消化器症状を多く認 め, $\mathrm{HD}$ 患者のD例に比し CAPD 患者のD例に高頻 度に症状を伴っていた．腎症の進行していない DM 患 者, または透析患者による過去の検討では, 胃運動障 害と消化器症状の程度は必ずしも相関しないとする報 告がある7,14,17,19). 本検討では, DM の罹患の有無にか かわらず $\mathrm{D}$ 例に該当しても症状を認めないものがあ 
り，このため胃運動障害単独では症状の発現に必ずし も関与せず，他の因子が加わって症状が発現すると考 えられる. 消化器症状を伴いやすい DM 透析患者の特 徴として HD, CAPD によらず，インスリン依存性糖 尿病 (IDDM), 血糖コントロールが不良, 神経, 血管 障害が強い等が挙げられている ${ }^{20)}$. 本検討では D例に 該当する DM-HD, DM-CAPD 患者間で，インスリン 使用者の数, 使用量, $\mathrm{HbAlc}$, 罹病年数に有意差を認 めず, DM の臨床背景に偏りはなかった。このため D 例に該当する $\mathrm{DM}$ 透析患者のうち $\mathrm{HD}$ 患者より CAPD 患者に症状を高頻度に認めた理由として, 透析 液貯留による腹腔内圧の上昇や糖の吸収等の影響が加 わって消化器症状が発現しやすくなると考えられ $ろ^{21)}$.

Eisenberg ら ${ }^{20)}$ DM 透析患者において CAPD と いう透析方法自体は gastroparesis diabeticorum の 増悪因子にならないと述べているが，我々の検討では その反対の傾向が示された。

透析患者に認められる栄養障害の要因として, 透析 不足, 胃運動障害, 心理学的問題等の食事捸取を減少 させる因子や，心血管障害，感染症等の合併症，蛋白 同化作用の障害, アシドーシス，透析治療自体の影響 等の種々の因子が挙げられる ${ }^{4,5}$. 本検討ではこのうち 胃運動障害について，断面的に D, N 例間で栄養指標 の比較することによって栄養状態との関連を検討し た。その結果 HD 患者では，DM, 非 DM 患者ともに， $\mathrm{D}, \mathrm{N}$ 例間で血清蛋白，筋肉量，PCR に差異を認めな かった. すなわち DM の罹患の有無によらず HD 患 者では, 胃運動障害を有しても消化器症状を呈するこ とがほとんどないために，食事摂取不足に陥ることな く, 栄養状態にも影響を及ぼさないものと考えられた。 一方，CAPD 患者では，DM 患者は非 DM 患者に 比し $\mathrm{D}, \mathrm{N}$ 例ともに血清アルブミンは低值のうえ， D 例はさらに\%MVで示される筋肉量は低值であった。 CAPD 患者では腹腔からの蛋白の喪失が血清アルブ ミン值に影響を与えるが22)，本検討では DM-CAPD, 非 DM-CAPD 患者間で腹膜機能，腹膜炎の発症頻度 には明らかな差を認めていない.さらに DM-CAPD 患者を $\mathrm{D}, \mathrm{N}$ 例に分けると， D例において体蛋白量を 表す筋肉量は最も低值であり，栄養障害が一層進行し ていると考えられた。 その要因として，本検討では BUN 值や PCR 值は, DM-CAPD 患者の D, N 例間 で有意差を認めなかったものの, DM-D 例では DM$\mathrm{N}$ 例や非 DM 透析患者に比し低值の傾向を示してお り，タンパク摂取が不十分であると推測される。すな わち DM-CAPD 患者では，胃運動障害を伴う場合消
化器症状を高率に発現し, 症状の変動に応じた不安定, 不十分な食事摂取となり低栄養状態に陷りやすい傾向 があると考えられた。

胃運動障害による消化器症状の対策として, 従来投 与されている metoclopramide, cisapride 等の胃運動 機能を調節する薬剤に加え, 症状の強い患者には, 近 年その効果が報告されている erythromycin の投与を 積極的に試みる価值があると思われる ${ }^{23,24)}$ 。 また DM 患者において透析を導入するにあたり，保存期から胃 運動障害による消化器症状が強い症例には CAPD よ り $\mathrm{HD}$ を選択する，あるいは同様に症状が強く栄養状 態が悪化しているDM-CAPD 患者には HD に変更す る等の配慮も必要と思われる.

\section{IV. 結 論}

アセトアミノフェン法による胃運動機能の評価か ら，DM 透析患者では非 DM 透析患者に比し高頻度 に胃運動障害を認めた。非 DM 透析患者や DM-HD 患者において, 胃運動障害は消化器症状, 栄養状態に ほとんど影響を及ぼさなと考えられたのに対し， DM-CAPD 患者では, 胃運動障害を伴う症例に高頻度 に消化器症状を有し, 栄養障害が進行していた。この ため DM 透析患者で, 胃運動障害を有する症例に CAPD を適応すると, 消化器症状を発生しやすく, こ れが栄養障害を引き起こす因子となり得ると考えられ た.

\section{文献}

1) Bergström J, Lindholm B : Nutrition and adequacy of dialysis: How do hemodialysis and CAPD patients compare? Kidney Int 43 (Suppl 40) : S3950,1993

2）日本透析医学会統計調査委員会：わが国の慢性透析療 法の現況（1994 年 12 月 31 日現在）。透析会誌 $29 ： 1-$ 22, 1996

3) Teraoka S, Maeda K, Toma H, Nihei H, Agishi T, Ota K, Ishikawa I, Shinoda A, Sato T, Koshikawa $\mathrm{S}$ : Registry report of dialysis therapy in Japan. In "Replacement of Renal Function By Dialysis" ed Jacobs C, Kjellstadt CM, Koch KM, Winchester JF, p 1376-1387, Kluwer Academic Publishers, Dordrechet, 1996

4) Schler CL, Worson M : Malnutrition and intradialytic parenteral nutrition in ESRD subjects. In "Principles and Practice of Dialysis" ed Henrich WL, p 277-286, Williams \& Wilkins, Baltimore, 1994

5) Bergström $\mathrm{J}:$ Why are dialysis patients malnouri- 
shed? Am J Kidney Dis 26：229-241, 1995

6) 伊藤正典, 畠山収一, 久慈一英, 宮内 勉, 森 保人, 伊藤利之, 北野博嗣, 泊 康男, 紺井一郎, 竹田亮祐 : 透析患者における胃排泄能の検討. 透析会誌 $25 ： 1219$ $-1224,1992$

7) Wright RA, Clemente R, Wathen R : Gastric emptying in patients with chronic renal failure receiving hemodialysis. Arch Intern Med 144 ：495-496, 1984

8）原沢 茂，崎田隆一，三輪正彦，鈴木荘太郎，谷 礼 夫，三輪 剛：Acetoaminophen による胃排出機能検 査法。医学のあゆみ $100 ： 632-634,1977$

9）中尾俊之, 藤原誠二, 田中剛二, 笠井健司, 宮原 正： 身体計測に基づく骨格筋肉量の測定について，公衆衛 生 $50 ： 357-358,1986$

10) Maroni BJ, Steinman TI, Mitch WE : A method for estimating nitrogen intake of patients with chronic renal failure. Kidney Int $27: 58-65,1985$

11) Bergström J, Furst P, Alvestrand A, Lindholm B : Protein and energy intake, nitrogen balance and nitrogen losses in patients treated with continuous ambulatory peritoneal dialysis. Kidney Int $44: 1048$ $-1057,1993$

12）宍戸 洋, 藤倉良裕, 我妻慎一, 関野 宏, 二木 源, 門間弘道, 高橋 寿, 安海 清, 浅木 茂, 後藤由夫： 慢性血液透析患者の胃排泄能，小腸通過時間の検討. 透析会誌 $19 ： 819-825,1986$

13) Brown-Cartwright D, Smith HJ, Feldman M : Gastric emptying of an indigestible solid in patients with end-stage renal disease on continuous ambulatory peritoneal dialysis. Gastroenterology 95 : 49-51, 1988

14) Bird NJ, Streather CP, O'Doherty MJ, Barton IK, Gaunt JI, Nunan TO : Gastric emptying in patients with chronic renal failure on continuous ambulatory peritoneal dialysis. Nephrol Dial Transplant 9:287 $-290,1993$

15）原沢 茂, 谷 礼夫, 野見山哲, 崎田隆一, 三輪正彦, 鈴木荘太郎, 三輪 剛：消化器疾患と胃排出能 第 1 報
消化性潰瘍とその再発。日内会誌 68：733-741，1979

16）鈴木吉彦，松岡健平：糖尿病性胃症に及ぼす糖尿病性 神経障害と血糖コントロールの影響. 糖尿病 $33 ： 635$ 640,1990

17) Horowitz M, Fraser $R$ : Disordered gastric motor function in diabetes mellitus. Diabetologia 37 : 543551, 1994

18) Abrahamsson $\mathrm{H}$ : Gastrointestinal motility disorders in patients with diabetes mellitus. J Intern Med 237 : 403-409, 1995

19) Horowitz M, Harding PE, Maddox AF, Wishart JM, Akkermans LMA, Chatterton BE: Gatric and oesophageal emptying in patients with type 2 (noninsulin-dependent) diabetes mellitus. Diabetologia $32: 151-159,1989$

20) Eisenberg B, Murata GH, Tzamaloukas AH, Zager PG, Avasthi PS: Gastroparesis in diabetics on chronic dialysis: clinical and laboratory associations and predictive features. Nephron $70: 296-300$, 1995

21) Mamoun $\mathrm{AH}$, Anderstam B, Lindholm B, Sodersten $P$, Bergström J : Peritoneal dialysis (PD) solutions with glucose and amino acids (AA) suppress appetite in the rat. J Am Soc Nephrol $5: 498,1994$

22) Heimburger $O$, Bergström J, Lindholm $B$ : Is serum albumin an index of nutritional status in continuous ambulatory peritoneal dialysis patients? Perit Dial Int 14:108-114, 1994

23) Gallar P, Oilet A, Vigil A, Ortega O, Guijo G : Gastroparesis : an important cause of hospitalization in continuous ambulatory peritoneal dialysis patients and role of erythromycin. Perit Dial Int 13 (Suppl 2) : s183-186, 1993

24) Richards RD, Davenport K, Mc Callum RN, McCallum RW : The treatment of idiopathic and diabetic gastroparesis with acute intravenous and chronic oral erythromycin. Am J Gastroenterol 88 : 203-207, 1993 